\title{
APLIKASI METODE FOAM MAT DRYING PADA PEMBUATAN BUBUK JAHE (Zingiber officinale)
}

\author{
Fifi Kurniasari", Indah Hartati dan Laeli Kurniasari \\ Jurusan Teknik Kimia, Fakultas Teknik, Universitas Wahid Hasyim Semarang \\ Jl. Menoreh Tengah X/22 Sampangan, Semarang 50236 \\ *Email : fifi_kurnias@yahoo.com
}

\begin{abstract}
Abstrak
Jahe merupakan salah satu jenis komoditas rempah yang memiliki beragam manfaat dan kegunaan. Jahe dalam bentuk bubuk diminati masyarakat karena lebih praktis dan lebih tahan lama. Salah satu metode pengeringan serbuk jahe yang dipandang tepat untuk diaplikasikan dalam proses produksi serbuk jahe adalah metode pengeringan busa (foam mat drying). Penelitian ini bertujuan untuk mengkaji proses pengeringan busa terhadap jahe dengan menggunakan tween 80 (foam agent) dan maltodekstrin sebagai bahan pengisi untuk membantu mempertahankan konsistensi busa. Proses percobaan menggunakan pengeringan tanpa foam untuk dibandingkan dengan variabel komposisi tween 80 (4\%,6\%,8\%) dan maltodekstrin $(10 \%, 15 \%, 20 \%)$. Didapatkan hasil perbandingan terbaik pada sampel 4 dengan kadar air 0,07\% pada menit ke 120. Hasil percobaan secara keseluruhan sudah memenuhi standar minimal produk makanan yaitu $<5 \%$.
\end{abstract}

Kata kunci : Jahe, Foam mat drying, Tween 80, Maltodekstrin

\section{PENDAHULUAN}

Jahe saat ini menjadi salah satu komoditas ekspor Indonesia. Data statistik menunjukkan volume ekspor jahe Indonesia mencapai 25 ribu ton pada tahun 2015 dan mengalami peningkatan setiap tahunnya (Ribtanti dkk., 2018). Hal yang mendasari pembuatan bubuk jahe adalah kebutuhan masyarakat akan produk bubuk jahe yang lebih praktis, murah dan tahan lama. Karim dan Wai. (1999) dan Kadam dkk. (2010) menyatakan jika metode Foam mat drying adalah salah satu metode pengeringan yang memiliki keunggulan yakni metode foam mat drying merupakan metode yang mudah diaplikasikan serta tidak membutuhkan bahan tambahan yang mudah dijumpai dan tidak mahal.

Pada dasarnya metode fom mat drying dilakukan dengan menambahkan bahan pembusa kedalam material yang akan dikeringkan. Bahan pembusa memiliki peran dalam mempercepat proses pengeringan, menurunkan kadar air bahan yang dikeringkan dan menghasilkan produk bubuk yang memiliki struktur remah (Murtala, 1999; Khotimah, 2006; Prasetyaningrum dkk., 2012). Kelebihan lain dari proses pengeringan dengan metode foam mat drying adalah bahwa proses pengeringan dapat dilakukan pada suhu yang relatif rendah.

Salah satu bahan pembusa yang bisa digunakan untuk produk pangan adalah tween
80, Bahan ini di golongkan dalam sufaktan non ionik dan di aplikasikan pada produk pangan tertentu serta secara umum di akui sebagai bahan tambahan makanan yang aman (GRAS) (Prasetyo dkk., 2005; Kumar dkk., 2007).

Selain bahan pembusa, dalam proses pengeringan dengan foam mat drying, perlu ditambahkan bahan yang dapat bersifat sebagai agen pengikat busa. Salah satu bahan yang dapat digunakan adalah maltodekstrin. Penambahan maltodekstrin juga dapat berfungsi membentuk lapisan tipis yang dapat meningkatkan laju proses pengeringan. Keberadaan lapisan tipis diantara material yang dikeringkan juga dapat meminimalkan terjadinya proses degradasi termal komponen aktif didalam bahan. Maltodekstrin juga dinyatakan berperan sebagai filler atau bahan pengisi dan berperan dalam meningkatkan volume dari material yang dikeringkan (Prasetyo dkk., 2005; Khotimah., 2006; Kumar dkk., 2007; Purbasari., 2016).

Menimbang kelebihan proses foam mat drying dan potensi keunggulan dan kegunaan serbuk jahe, maka dalam publikasi ini disajikan hasil kajian mengenai proses foam mat drying jahe.

\section{METODOLOGI}

Jahe merupakan bahan baku utama dalam penelitian ini. Bahan-bahan lain yang digunakan terdiri atas aquadest, maltodekstrin 
dan tween 80. Proses pengeringan dilakukan menggunakan tray dryer. Penelitian dilakukan dengan menimbang jahe basah yang sudah dihaluskan sebanyak 25 gram dan kemudian ditambah dengan maltodekstrin dengan variasi $10 \%, 15 \%, 20 \%$ dan tween 80 dengan variasi $4 \%, 6 \%, 8 \%$ dengan suhu pengeringan $65{ }^{\circ} \mathrm{C}$. Adapun variasi komposisi :

Sampel tanpa foam $=$ Jahe 25 gram + Non Foam

Sampel $1=$ Jahe 25 gram + Maltodekstrin 10\% + Tween $804 \%$

Sampel $2=$ Jahe 25 gram + Maltodekstrin 15\% + Tween $804 \%$

Sampel 3 = Jahe 25 gram + Maltodekstrin 20\% + Tween $804 \%$

Sampel $4=$ Jahe 25 gram + Maltodekstrin $10 \%$ + Tween $806 \%$

Sampel 5 = Jahe 25 gram + Maltodekstrin 15\% + Tween $806 \%$

Sampel $6=$ Jahe 25 gram + Maltodekstrin 20\% + Tween $806 \%$

Sampel $7=$ Jahe 25 gram + Maltodekstrin 10\% + Tween $808 \%$

Sampel $8=$ Jahe 25 gram + Maltodekstrin $15 \%$ + Tween $808 \%$

Sampel $9=$ Jahe 25 gram + Maltodekstrin 20\% + Tween $808 \%$

\section{HASIL DAN PEMBAHASAN}

Hasil Uji Pengeringan Tanpa Foam Pada Suhu $65^{\circ} \mathrm{C}$.

Sampel jahe yang dikeringkan tanpa penambahan foam dikeringkan menggunakan alat tray dryer dengan suhu $65{ }^{\circ} \mathrm{C}$ selama 210 menit. Data Kandungan air dalam sampel tanpa foam mengalami pengurangan secara perlahan dibanding sampel dengan penambahan maltodekstrin dan tween 80. Berat akhir sampel di dapat setelah kadar air konstan lebih ringan dibanding dengan sampel dengan foam yaitu 1,96 gram dengan kadar air awal bahan $92,16 \%$ dan kadar akhir bahan $0,08 \%$.

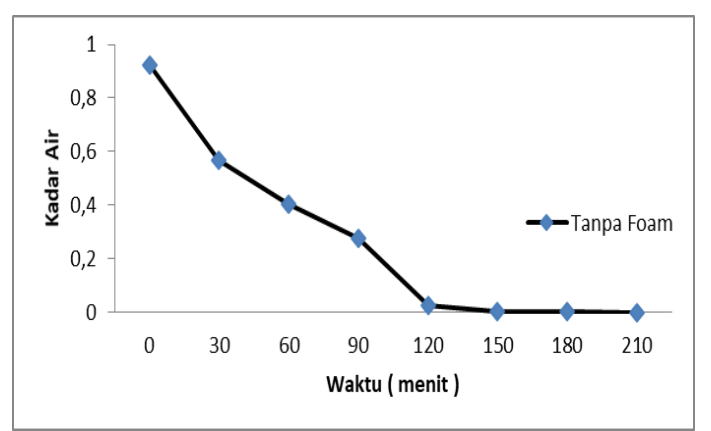

Gambar 1. Grafik Hubungan antara kadar air terhadap waktu pengeringan tanpa foam

Pengaruh Penambahan Tween $804 \%$ dan Maltodekstrin $10 \%, 15 \%, 20 \%$ dan pada Suhu Pengeringan $65^{\circ} \mathrm{C}$.

Data kadar air sampel jahe yang dikeringkan dengan penambahan tween 80 sebesar $4 \%$ dan ditambah dengan maltodekstrin dengan variasi konsentrasi sebesar 10\%, 15\%, 20\% disajikan pada Gambar 2. Hasil penelitian menunjukkan jika pada percobaan penambahan tween $804 \%$ dan maltodekstrin 10\%, 15\%, 20\%, presentase kadar air pada menit ke 150 untuk sampel 1 adalah sebesar $0,08 \%$, sampel 2 sebesar $0,18 \%$ sedangkan sampel 3 adalah sebesar $0,25 \%$.

Dari ke tiga sampel tersebut dapat disimpulkan jika pengeringan terbaik didapat pada sampel 1 dengan kadar air paling rendah diantara 2 sampel lainnya. Lebih lanjut, jika dibandingkan dengan proses pengeringan sampel yang tidak diberi foam, sampel tanpa penambahan foam membutuhkan waktu yang lebih lama untuk mencapai kadar air yang rendah.

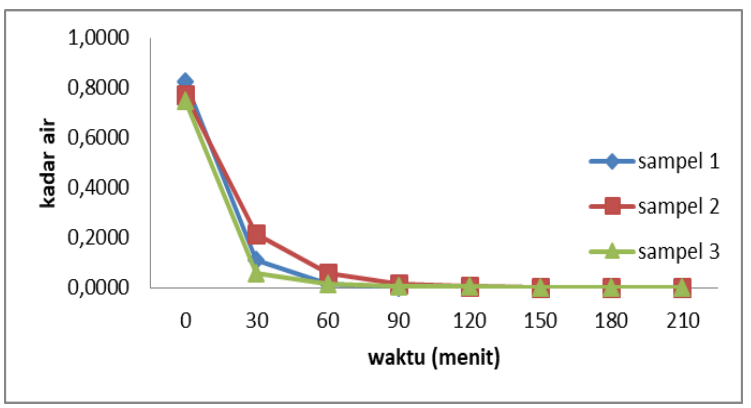

Gambar 2. Grafik Hubungan antara kadar air terhadap waktu Pengeringan sampel 1, 2 dan 3

Dari hasil percobaan dapat dilihat kadar air pengeringan dengan foam lebih rendah dibanding pengeringan tanpa foam yang 
presentase kadar air akhir nya $0,08 \%$ dan waktu pengeringan yang lebih lama yaitu 210 menit.

Pengaruh Penambahan Tween $806 \%$ dan Maltodekstrin $10 \%, 15 \%, 20 \%$ dan pada Suhu Pengeringan $65^{\circ} \mathrm{C}$.

Data kadar air sampel jahe yang dikeringkan dengan penambahan tween 80 sebesar $6 \%$ dan ditambah dengan maltodekstrin dengan variasi konsentrasi sebesar 10\%, 15\%, 20\% disajikan pada Gambar 3. Hasil penelitian menunjukkan jika pada percobaan penambahan tween 80 sebesar $6 \%$ dan maltodekstrin $10 \%, 15 \%, 20 \%$, waktu pengeringan dengan penambahan tween 80 sebanyak $6 \%$ ternyata lebih singkat dibanding sampel tanpa foam maupun sampel dengan penambahan tween $804 \%$.

Untuk mencapai kadar air standar minimal produk makanan, yaitu < 5\% sampel 4 mampu memberikan waktu pengeringan 30 menit lebih cepat dari pada sampel foam 5 dan 6 . Pada menit ke 120 diperoleh kadar air pada sampel 4 sebesar $0,07 \%$ dan sampel 5 diperoleh kadar air sebesar 0,26\% dan sampel 6 diperoleh kadar air bahan sebesar 0,27\%. Pada ketiga sampel, didapat pengeringan paling efisien yaitu sampel 4 dengan kadar air pada menit ke 120 paling rendah.

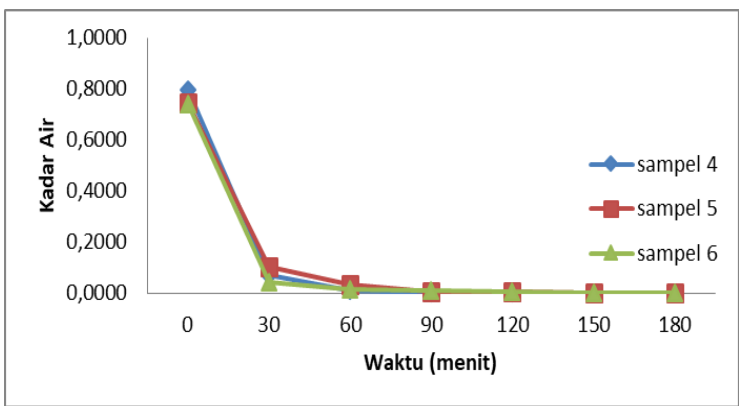

Gambar 3. Grafik Hubungan antara kadar air terhadap waktu pengeringan sampel 4, 5 dan 6

Pengaruh Penambahan Tween $808 \%$ dan Maltodekstrin $10 \%, 15 \%, 20 \%$ dan pada Suhu Pengeringan $65^{\circ} \mathrm{C}$.

Data kadar air sampel jahe yang dikeringkan dengan penambahan tween 80 sebesar $8 \%$ dan ditambah dengan maltodekstrin dengan variasi konsentrasi sebesar 10\%,15\%, 20\% disajikan pada Gambar 4. Dari grafik dengan penambahan tween $80 \quad 8 \%$ dan variasi maltodektrin $10 \%, 15 \%, 20 \%$, ternyata dengan penambahan zat pembuih (tween 80) dengan persentase yang lebih banyak mempercepat pengeringan.

Untuk membandingkan pengeringan terbaik pada variabel penambahan maltodekstrin, dapat dilihat pada menit ke 120. Sampel 7 menunjukkan presentase kadar air 0,07\%, sampel 8 menunjukkan kadar air $0,14 \%$ dan sampel 9 pada menit ke 120 sama besar dengan sampel 7 yaitu $0,07 \%$. Meskipun demikian, pengeringan sampel 7 lebih efisien karena dengan hanya penambahan maltodekstrin $10 \%$ saja, kadar air didapat sudah sama dengan penambahan maltodekstrin $20 \%$.

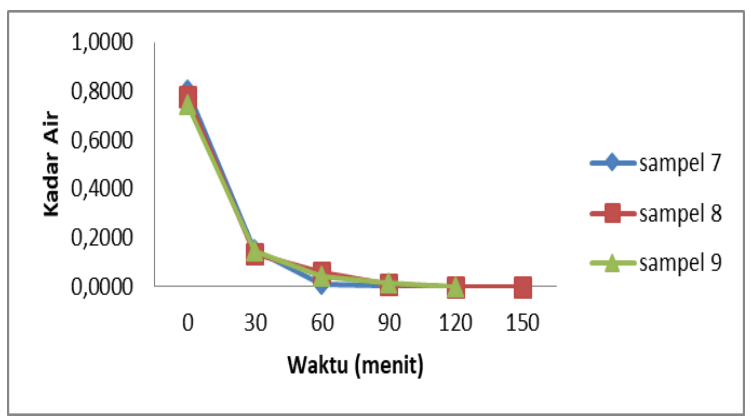

Gambar 4. Grafik Hubungan antara kadar air terhadap waktu pengeringan sampel 7,8 dan 9

\section{Hasil Uji Kromatografi Gas - Spektroskopi Massa ( GC-MS )}

Menurut Eze dan Agbo. (2011), jahe kering dinyatakan mempunyai kadar air 7-12\%, minyak atsiri $1-3 \%$, oleoresin $5-10 \%$, pati $50-55 \%$ dan sejumlah kecil protein, serat, lemak sampai $7 \%$. Pada hasil uji GCMS yang telah dilakukan terhadap serbuk jahe yang dikeringkan menggunakan metode foam mat drying menunjukkan jika pada menit ke 10.240 terdeteksi Zingerone dengan presentase $0,601 \%$, spectrum pada waktu 10.580 menit terdeteksi Vitamin A aldehyde (Retinal) dengan presentase $0,718 \%$, spectrum pada waktu 11.310 menit terdeteksi Oleic Acid dengan presentase $1,816 \%$, spectrum pada waktu 13.581 menit terdeteksi Palmitic Acid dengan presentase $5,557 \%$, pada menit ke 15.931 terdeteksi komponen cis-Vaccenic Acid sebanyak 63,092\%, kemudian pada menit ke 17.101 terdeteksi Gingerol dengan presentase $12.766 \%$ dan di menit ke 18.162 terdeteksi Gingerol dengan presentase 15.405\% (Gambar 5 dan Tabel 1). 


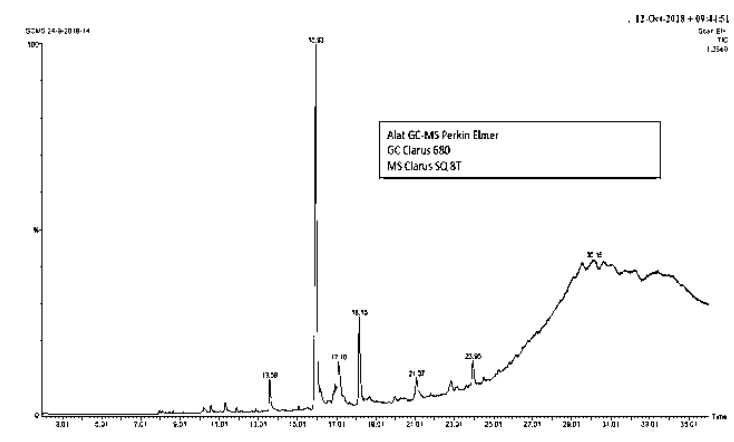

Gambar 5. Profil kromatogram serbuk jahe yang dikeringkan menggunakan metode foam mat drying

Tabel 1. Data waktu retensi dan persentase luas area komponen serbuk jahe

\begin{tabular}{cccc}
\hline No & RT & \%Area & Komponen \\
\hline 1 & 10.24 & $0.601 \%$ & Zingeron \\
2 & 10.58 & $0.718 \%$ & Retinal \\
3 & 11.31 & $1.861 \%$ & Oleic Acid \\
4 & 13.581 & $5.557 \%$ & Palmitic Acid \\
5 & 15.931 & $63.092 \%$ & cis-Vaccenic acid \\
6 & 17.101 & $12.766 \%$ & Gingerol \\
7 & 18.162 & $15.405 \%$ & Gingerol \\
\hline
\end{tabular}

\section{KESIMPULAN}

Berdasarkan penelitian yang telah dilakukan dapat disimpulkan bahwa sampel terbaik masing-masing penambahan tween 80 4\%, 6\% dan 8\%. Pada penambahan tween $804 \%$, pengeringan terbaik yaitu sampel 1 dengan kadar air $0,08 \%$ pada menit ke 150 , pada penambahan tween 80 $6 \%$ pengeringan terbaik yaitu sampel 4 , dengan kadar air $0,07 \%$ pada menit ke 120 dan pada penambahan tween $80 \quad 8 \%$ pengeringan terbaik yaitu pada sampel 7 dengan kadar air $0,07 \%$ pada menit ke 120 .

Dari ketiga sampel terbaik pengeringan yang paling efisien adalah sampel 4, dikarenakan dengan hanya penambahan tween 80 6\% dan maltodekstrin 10\% kadar air pada menit ke 120 sudah mencapai $0,07 \%$.

\section{DAFTAR PUSTAKA}

Eze J.I., dan Agbo K.E., 2011. Comparative studies of sun and solar drying of peeled and unpeeled ginger. American Journal of Scientific and Industrial Research. ISSN: 2153-
$649 \mathrm{X}$, doi:10.5251/ajsir.2011.2.2.136.143

Kadam D.M., RT.Patil and P. Kaulshik, 2010. Foam Mat Drying of Fruit and Vegetable Products. Central Institut of Post Harvest Engineering and Technology (CIPHET), Ludhiana, India.

Karim, A.A. and C.C. Wai. 1999. Foammat drying of starfruit (Averrhoa carambola L.) puree. Stability and air drying characteristics. Food Chemistry, 64: 337-343.

Khotimah, K. 2006. Pembuatan Susu Bubuk dengan Foam Mat Drying: Kajian Pengaruh Bahan Penstabil terhadap Kualitas Susu Bubuk. Jurnal Protein. Vol 13.No 1:44-51.

Kumar, R.P., Kailappan, R., Viswanathan, R., Raghavan and Ratti, C. 2007. Foam Mat Drying of Alphonso Mango Pulp. Drying Technology, 25:357-365.

Murtala, S. S. 1999. Pengaruh Kombinasi Jenis dan Konsentrasi Bahan Pengisi Terhadap Kualitas Bubuk Sari Buah Markisa Siul (Passiflora edulis F. Edulis). (Tesis) Pasca Sarjana Universitas Brawijaya Malang.

Prasetyaningrum, A., Asiah, N., Sembodo, R. 2012. Aplikasi Metode Foam-Mat Drying pada Proses Pengeringan Spirulina. Jurnal Teknologi Kimia dan Industri. Vol 1 (1):461-467.

Purbasari D, 2016. Aplikasi Metode Foam mat drying dalam pembuatan bubuk susu kedelai instan

Prasetyo, S., Agustini, dan Suharto. 2005. Pembuatan bubuk jeruk dengan metode pengeringan busa. J. Reaktor, 9 (1): 50-57.

Ribtanti E.E., Qonita R.A., And Fajarningsih, R.U. 2018. The Competitiveness of Medicinal Plants In Central Java Indonesia. IOP Conf. Series: Earth and Environmental Science $\quad 142 \quad$ (2018) 012018 Doi: $10.1088 / 1755-$ 1315/142/1/012018 